\title{
Are We All Global Historians Now? An Interview with David Armitage
}

\section{Citation}

Armitage, David, Jacobs, Jaap, and van Ittersum, Martine. 2012. Are we all global historians now? An interview with David Armitage. Itinerario 36(2): 7-28.

\section{Permanent link}

http://nrs.harvard.edu/urn-3:HUL.InstRepos:10717959

\section{Terms of Use}

This article was downloaded from Harvard University's DASH repository, and is made available under the terms and conditions applicable to Open Access Policy Articles, as set forth at http:// nrs.harvard.edu/urn-3:HUL.InstRepos:dash.current.terms-of-use\#OAP

\section{Share Your Story}

The Harvard community has made this article openly available.

Please share how this access benefits you. Submit a story.

\section{Accessibility}




\title{
Are We All Global Historians Now? An Interview with David Armitage
}

\author{
by \\ Martine van Ittersum \\ and Jaap Jacobs
}

The interview took place on a splendid summer day in Cambridge, Massachusetts. The location was slightly exotic: the interviewers had lunch with David Armitage at Upstairs at the Square, an eatery which sports pink and mint green walls, zebra decorations, and even a stuffed crocodile. What more could one want?

Armitage was recently elected Fellow of the Australian Academy of the Humanities. At the time of the interview, he was just about to take over as Chair of the History Department at Harvard University. His long-awaited Foundations of Modern International Thought (2013) was being copy-edited for publication. ${ }^{1}$ Granted a sneak preview, the interviewers can recommend it to every Itinerario reader. In short, it was high time for Itinerario to sit down with one of the movers and shakers of the burgeoning field of global and international history for a long and wide-ranging conversation.

Could you tell us something about your life story? Where were you born, where did you grow up, what is your family background?

I had a very land-locked childhood, which, at least superficially, gave no indication that I would be interested in international and global history later in life. I say superficially because, as I think back, over the years about aspects of my family history, I can see that the seeds were already there, although I did not realize it at the time. My father, a marine engineer, did his British National Service in the Merchant Navy and then stayed on for some years afterwards, spending most of his time on the so-called 'MANZ-run', which took in Montreal, Australia and New Zealand via year-long tours of the Pacific. It was perhaps an indication that I was going to have a global future as well, and was possibly also the genetic origin of my recent interest in Pacific history. When I was a child, my father spoke very little about his activities at sea. But I occasionally picked up hints, when I saw occasional photographs of his travels or he mentioned a visit to Australia here, having been in New York there. Without putting too much of a burden on the accidents of family history, I think that it was significant both that my father had had a distinctly global career in his twenties and that he spoke so little about it. That seems characteristic of the way Britain itself in my childhood was a power with international and global connections, but maintained a great amnesia about speaking of these connections or acknowledging how much the world beyond Britain had shaped British history itself.

${ }^{1}$ David Armitage, Foundations of Modern International Thought (Cambridge: Cambridge University Press, 2013). 
And I also remember as another thread of family history that my great-grandfather in the years before the First World War had wanted to escape his family. He was something of a wastrel, not to be relied upon. He went on a long and rather mysterious tour of North America in 1912/13. There was clearly a gene for Wanderlust in the family, even though it was rarely spoken about, and was thought about in somewhat dangerous terms. I have the postcards that my grandmother's family received from him, all of which were dismayingly, suspiciously brief about what he was up to, where he was going, etc. There was clearly a strain in my family-my father's global career through the Merchant Navy, my great-grandfather with his Wanderlust, taking him through North America - that I must have picked up in a career that's taken me to the US for the past twenty years, when I've lectured on six continents. (Antarctica has eluded me so far.) By contrast, most of my relatives have stayed very close to the unremarkable town where I was born, Stockport, just south of Manchester. It was a spinning and hat-making town, one of the cradles of the Industrial Revolution, although all of that industry was already receding when I was a child.

There is a third coincidence which, looking back, perhaps made me into an imperial and ultimately a global historian. My mother went into labor on the day Winston Churchill was buried, the last living symbol of the British Empire. I now like to think, without being completely self-aggrandizing, that the weekend the British Empire was buried in the figure of Winston Churchill was a rather appropriate time for a self-consciously postimperial historian to be born. As the empire was passing away in the early 1960s, I was born as part of a generation of historians that would regard the British Empire as history, as something to look back on, but no longer as a living force. I was part of a generation that came of age in the late 1970s and early 1980s, when the last wisps of the British Empire were given up. It conditioned the way my generation thought about British history in relation to its larger international and imperial contexts. It was hardly a coincidence that I should come out of an amnesiac Britain trying to forget its international, imperial and global connections, or that I grew up as part of a generation which was determined to recover those broader contexts, i.e. the impact of the wider world on Britain and the impact of Britain on the wider world as well.

One realizes in retrospect that every part of British society was deeply enmeshed with the Empire and Commonwealth, even people coming from landlocked places. However, this was little talked about, something I call imperial amnesia. My parents contemplated emigrating to Nova Scotia in the late 1960s, for example. This was entirely typical of upper- and middle-class whites moving to the Empire in the twentieth century. David Cannadine's reflections on the hidden but multiple imperial connections of his family in Birmingham suggest a very similar profile to that of my own family. ${ }^{2}$

White settlers born in the Empire were educated at Cambridge and Oxford, on the understanding that you would return to place where you came from. The great historian of political thought, J. G. A. Pocock, was born in New Zealand and still retains a very

\footnotetext{
${ }^{2}$ David Cannadine, “An Imperial Childhood”, Yale Review, 86, 2 (April 1998), pp. 2846.
} 
strong identity as a New Zealander. It inflects almost everything he writes, increasingly self-consciously in recent years as well. His skepticism about Europe as a project has always come from his New Zealand identity. In his view, Britain faced a choice between Europe and the white settler Commonwealth at the beginning of 1970s, and made a choice for Europe and against the settler empire. It was exactly at that moment that Pocock wrote his first essays on the 'New British History'. He envisioned a metropolitan Britain as part of a congeries, a global nexus of commonwealth settler societies across the globe, a set of islands scattered around the globe, including New Zealand. The 'New British History' came from that charged political moment and that set of choices. ${ }^{3}$

You were educated at the University of Cambridge. What difference did it make to your intellectual interests and academic career?

I benefited from excellent teaching at Stockport Grammar School, most notably an inspirational history master by the name of Nicholas Henshall. ${ }^{4}$ A very fine publishing scholar in his own right, he had done a special subject with Geoffrey Elton at Cambridge, and later started a Ph.D. at the University of Manchester, which he did not complete. I am convinced that I got from Henshall as good a history education as I would have had, had I done history at Cambridge. Henshall gave me a real feel for what it was like to work at the highest pitch of scholarship, absent immediate access to the archives. I am immensely grateful for that. Nick is a really inspirational figure: we all have someone like that, especially in our school careers, who showed you the excitement of intellectual life, intellectual work, of whatever kind it might be.

I went to the University of Cambridge in 1983 to read English, in probably the only act of rebellion in my whole life. I was supposed to enter Cambridge as a History student, but at school I revolted and opted to do English instead. Although I lacked the terminology, I knew that I wanted to be what we might now call a cultural and intellectual historian. If there is one single book that made me want to be a historian, it is Frances Yates's The Art of Memory (1966). ${ }^{5}$ I still have the copy that I first read at the age of 15 . To me, it was so thrillingly unusual in what it revealed about the past. These were aspects of the past that I had never encountered before. And Yates did it in such an elegant and revelatory way. I decided that this was the kind of history that I wanted to do. At Cambridge in the

\footnotetext{
${ }^{3}$ J. G. A. Pocock, 'British History: A Plea for a New Subject', New Zealand Journal of History, 8 (1974), pp. 3-21, reprinted with minor modifications in Journal of Modern History 47 ( 1975 ), pp. 601-24, and again in Pocock, The Discovery of Islands: Essays in British History (Cambridge: Cambridge University Press, 2005), pp. 24-43; see also Richard Bourke, 'Pocock and the Presuppositions of the New British History', The Historical Journal 53, 3 (2010), pp. 747-70.

${ }^{4}$ N. G. Henshall, The Myth of Absolutism: Change and Continuity in Early Modern European Monarchy (London: Longman, 1992); Henshall, The Zenith of European Monarchy and its Elites: The Politics of Culture, 1650-1750 (Basingstoke: Palgrave Macmillan, 2010).

${ }^{5}$ Frances A. Yates, The Art of Memory (London: Routledge and Kegan Paul, 1966; rpt. Harmondsworth: Peregrine, 1978).
} 
early 1980s, the undergraduate History Tripos was still very much focused on political and institutional history. I had read everything by Geoffrey Elton and his followers by about the age of 16: very impressive institutional and political history, but not what I wanted to do myself. In order to become a cultural and intellectual historian, I knew I needed training in the reading of texts, i.e. interpretation and hermeneutics, with historical sensitivity. The Cambridge English Tripos-formally entitled "English Literature, Life and Thought"-seemed the more sensible option. I had no intention of pursuing an academic career at that point. I wanted to be a barrister, which meant doing two years of English and one year of Law. My plan was totally derailed by surprisingly good exam results in English in my first and second years. Everyone said: 'you should carry on with it, because you are apparently very good at it'. Since I had by then lost my rebellious streak, this is what I did.

Following a B.A. in English, I immediately started with a Ph.D. in English. I spent two years on Shakespeare's classical sources, particularly Shakespeare's use of Ovid.

Halfway through that process, I discovered that almost all the Ovidian poets in sixteenthcentury England had also written poems about English colonial enterprises in Virginia or Guiana. I thought: this is a much more interesting topic, this is where the juices start flowing, this is something novel that has not been talked about before. I faced a fork in the road. To cut a long story relatively short: rereading John Milton's Paradise Lost was the point on which my work pivoted back from literary scholarship to intellectual history. There are two great narratives in Paradise Lost: a) the narrative of the Fall of Mankind, and b) the narrative of Satan's discovery of the New World. There are references all the way through to Satan as a voyager, a traveller, going to a New World, where he encounters the native peoples. The poem is saturated with the language of empire. I thought: 'why was this the case?' Why did Milton reflect in the late 1650s and early 1660s, when writing Paradise Lost, on contacts with the New World beyond Europe? Why did he mention empire, discovery and colonization, oftentimes with a negative valence? I related that to Milton's republicanism, his commitment to classical republicanism, to neo-Roman thought. ${ }^{6}$ This was the topic I had been looking for: the relationship between republicanism and empire. I took this project with me when I left Cambridge in 1988, right in the middle of my Ph.D., and went to Princeton for two years on a Commonwealth Fund Harkness Fellowship, in order to retool as a historian.

I was particularly encouraged do so by J. H. Elliott, who was then at the Institute of Advanced Study at Princeton. Elliott's The Old World and the New, 1492-1650 (1970), based on his 1969 Wiles Lectures at Queen's University, Belfast, had been a great

\footnotetext{
${ }^{6}$ David Armitage, 'John Milton: Poet Against Empire,' in Armitage, Armand Himy and Quentin Skinner, eds., Milton and Republicanism (Cambridge: Cambridge University Press, 1995), pp. 206-25; see also Armitage, 'Literature and Empire,' in Nicholas Canny, ed., The Oxford History of the British Empire, I: The Origins of Empire (Oxford: Oxford University Press, 1998), pp. 99-123.
} 
inspiration to me. ${ }^{7}$ (I was therefore more than usually honored and delighted to follow Elliott as the Wiles Lecturer at Queen's in 2010.) John himself was extraordinarily kind to me and had a decisive influence on my career. Although based in Princeton, he retained a house in Cambridge, to which he returned every summer. I met him one summer when he was in Cambridge, explained that I had a fellowship to go to the US, and that I wanted to work on the relationship between English literature and English imperial ventures in the Americas. He immediately suggested I to come to Princeton. Since the Institute of Advanced Study does not take graduate students, he could not officially supervise me, but offered to help in any way he could. He gave me the names of Princeton faculty members I might work with, including Lawrence Stone, Natalie Zemon Davis and John Murrin in History and David Quint and Victoria Kahn in Literature. He was extraordinarily generous, really decisive at that point in helping me to move my intellectual framework towards the US and American academia, Princeton in particular. He was amazingly generous to someone he had never met before, to whom he had no prior connection. As a side-note, I should say that I have been struck at various points by how generous extremely senior scholars can be to junior scholars and how decisive this can be in one's academic life. Throughout my own career, I have tried to follow Elliott's example as much as I can, in my own, faltering way. I realize that I owe so much to so many generous people, who helped me at critical moments in my career, when they really had no reason to. Elliott was the first one to do that for me. He did not just introduce me to Princeton scholars, but also - here is where the irony comes in - to many of the great Cambridge historians who would play a decisive influence in my career for the next ten years. It was at Princeton that I first met Anthony Pagden, Richard Tuck, Chris Bayly, Linda Colley and David Cannadine. It was at Princeton as well that I first really came across the work of Quentin Skinner, whose name had never even been mentioned to me in the five years I spent at Cambridge studying English.

So Princeton, not Cambridge, was the decisive influence in your career?

You might say that; I couldn't possibly comment. However, the pivotal figure in my career is Quentin Skinner, a founding member of the so-called "Cambridge School" of the History of Political Thought, who, like Pocock, also had a family background in the Empire. ${ }^{8}$ Quentin saved my academic life. In my second year at Princeton, I had reached a crisis point. I realized that I could not in good conscience continue with a Ph.D. in English. I wanted to be in a History Department and to work as a historian. It became necessary to throw myself at the mercy of at least one historian in order to make the transition. By that time, I had read a great deal of Skinner's work. Quentin was then publishing his major work on republicanism, ${ }^{9}$ which fit very closely with my interests at

\footnotetext{
${ }^{7}$ J. H. Elliott, The Old World and the New, $1492-1650$ (Cambridge, 1970). Itinerario interviewed Sir John Elliott in 1995: 'An Englishman Abroad: Sir John Elliott and The Hispanic World', Itinerario 19, 2 (July 1995) pp. 15-25.

${ }^{8}$ Quentin Skinner's father was a former naval officer who joined the Colonial Service and served in West Africa for most of Skinner's childhood: see interview with Alan Macfarlane, 10 January 2008: http://www.sms.cam.ac.uk/media/1130434.

${ }^{9}$ Quentin Skinner, Machiavelli (Oxford: Oxford University Press, 1981); Machiavelli,
} 
that stage. I very much wanted to work with him. It was the last chance to rescue myself as a historian. Through a friend, I got in touch with him. On a brief visit from Princeton, we had lunch and I explained my project. With what I soon discovered is his characteristic generosity and grace, he agreed to take me on as a student and to help me make the transition to the History Ph.D. program at Cambridge. He did exactly that. He did all the necessary administrative legwork to transfer me from English to History. The rest is history - or, rather, History. It was unforced, unanticipated generosity on Quentin's part, and an enormous vote of confidence. When I joined the History Ph.D. program at Cambridge, it was the absolute zenith of intellectual history and history of political thought at Cambridge in terms of the breath and depth of the group I was part of. Among my contemporaries were Annabel Brett, Joan-Pau Rubiés, and Andrew Fitzmaurice. $^{10}$

It was a really extraordinary moment in terms of early-modern intellectual history, the move towards connecting intellectual history with extra-European history and the history of colonization. Richard Tuck was independently beginning his work that led to The Rights of War and Peace (1999). ${ }^{11}$ There was in different areas a move towards the international, colonial, imperial, global setting of early-modern intellectual history in particular. Sometimes we worked entirely independently of each other, but then we discovered that we arrived at the same set of topics via different routes. There were common seminars: the famous Monday night seminar in the History of Political Thought, run for many years by Skinner and John Dunn-yet another founder of the Cambridge School who came from "a sort of imperial family" in British India ${ }^{12}$-and which still continues today. Together with Joan-Pau Rubiés, I organized a seminar on 'Cultural Encounters in the Early-Modern World', a colonial history and European expansion seminar with a cultural/intellectual history focus. In doing so, we had the full support of Peter Burke, a fellow-Fellow of mine at Emmanuel College at the time.

The Prince, trans. Russell Price, ed. Quentin Skinner (Cambridge: Cambridge University Press, 1988); Gisela Bock, Quentin Skinner and Maurizio Viroli, eds., Machiavelli and Republicanism (Cambridge: Cambridge University Press, 1990).

${ }^{10}$ Annabel Brett, Liberty, Right, and Nature: Individual Rights in Later Scholastic Thought (Cambridge: Cambridge University Press, 1997); Brett, Changes of State: Nature and The Limits of The City in Early Modern Natural Law (Princeton, N.J.: Princeton University Press, 2011); Andrew Fitzmaurice, Humanism and America: An Intellectual History of English Colonisation, 1500-1625 (Cambridge: Cambridge University Press, 2003); Joan-Pau Rubiés, Travel and Ethnology in the Renaissance: South India through European Eyes, 1250-1625 (Cambridge: Cambridge University Press, 2000); Rubiés, Travellers and Cosmographers: Studies in the History of Early Modern Travel and Ethnology (Aldershot: Ashgate, 2007).

${ }^{11}$ Richard Tuck, The Rights of War and Peace: Political Thought and the International Order from Grotius to Kant (Oxford: Clarendon Press, 1999).

12 John Dunn, interview with Alan Macfarlane, 5 March 2008: http://www.sms.cam.ac.uk/media/1116035. 
You taught at Columbia University from 1993 until 2004. How different was American academia from what you were used to back in Britain? Do you feel that it was a crucial step in your academic and professional career?

By extraordinary good fortune, a junior position in British history opened up at Columbia University just as I finished my junior research fellowship at Emmanuel College,

Cambridge, a year later, in 1993. David Cannadine held the senior position in British History at Columbia. His extraordinary generosity, inspiration, and camaraderie began when I went for my interview at Columbia University and continued throughout the time that I was there. He was an immensely supportive, energizing figure, who was taking his own imperial turn in those years as well. ${ }^{13}$

David and I very much saw eye to eye in terms of where British history was going. There was a palpable sense among British historians, particularly in the US, that the field was dwindling into insignificance, that the tweedy Anglophilia that had sustained it for decades was no longer viable, as America was becoming a more outward-looking and global society. If British history was to survive as a teaching and research subject, a subject in which major universities would continue to hire, we had to reconsider its position in the wider academic ecology in the US. In the late 1990s, the North American Conference on British Studies undertook a self-study of the field. ${ }^{14}$ Its report concluded that a turn towards empire, towards Britain's international connections, towards the global setting of British history was going be essential to save the field, just as it was intellectually unignorable as a major aspect of the field-it had been largely overlooked, except under the rubric of imperial history. I arrived at the right moment in the US, just when that move was taking place.

There is one other big difference between the US and British academia: the breadth demanded in teaching, the fact that one has to teach British history to a non-British audience, in the context of a very diverse student body. When I started teaching at Columbia, I had to think from the bottom up about the larger stories, the larger narratives into which I would put British history, which would be narratives intersecting with colonial American history, with Atlantic History, with imperial history, with global history. Just in the course of writing my first series of lectures on British history for students at Columbia University, I was being pushed to think in my capacity as a teacher-even before I took this turn in my research--to think outwards, to think imperially, to think globally. That was decisive for my career, as was a succession of brilliant graduate students at Columbia and now Harvard who have taught me more than I could ever have taught them about expanding the boundaries of established histories. ${ }^{15}$

${ }^{13}$ David Cannadine, Ornamentalism: How the British Saw their Empire (London: Allen Lane, 2000).

${ }^{14}$ NACBS Report on the State and Future of British Studies in North America (1999): http://www.nacbs.org/documents/reportonfield1999.html.

${ }^{15}$ Among them, James Delbourgo, A Most Amazing Scene of Wonders: Electricity and Enlightenment in Early America (Cambridge, Mass.: Harvard University Press, 2006); Ted McCormick, William Petty and the Ambitions of Political Arithmetic (Oxford: 
I taught the Contemporary Civilization course at Columbia University, a two thousand year text-based, seminar/discussion-based survey of (mainly) Euro-American intellectual history, Plato to Rawls and beyond. That was the most exciting teaching I have ever done. Its chronological breadth over the very longue durée was salutary. It was in some sense my education as an intellectual historian, inculcating an interest in questions over the longue durée that have become increasingly urgent in my current work. Half of my teaching at Columbia University was in the Core Curriculum, in fact, which was one of the great attractions for me. I was very committed to it, and chaired the Contemporary Civilization course at Columbia in 2002-04.

\section{What about your research and publications at this time?}

In the 1990s, I did research in the New York Public Library, Columbia University Library, and the Folger Shakespeare Library in Washington DC, among other places. I went back to Britain in the summer time in order to do research in London and Edinburgh. I did quite a lot of Scottish history as part of the larger British project I was working on, to make sure that it was truly British, representing both the English and Scottish experiences. ${ }^{16}$

I published an edition of Bolingbroke's political writings in $1997 .{ }^{17}$ Bolingbroke played an important role in my Ideological Origins of the British Empire (2000). ${ }^{18}$ He was among the first to theorize Britain as a blue-water empire in the 1730s. In the course of

Oxford University Press, 2009); Lisa Ford, Settler Sovereignty: Jurisdiction and Indigenous People in America and Australia, 1788-1836 (Cambridge, Mass.: Harvard University Press, 2010); Travis Glasson, Mastering Christianity: Missionary Anglicanism and Slavery in the Atlantic World (New York: Oxford University Press, 2011); Philip Stern, The Company-State: Corporate Sovereignty and the Early Modern Foundations of the British Empire in India (New York: Oxford University Press, 2011); Ryan T. Jones, Empire of Extinction: A Natural History of Russian Expansion in the Eighteenth-Century North Pacific (forthcoming, Oxford University Press); Tristan M. Stein, "The Mediterranean and the English Empire of Trade, 1660-1748" (unpublished $\mathrm{PhD}$ thesis, Harvard University, 2012).

${ }^{16}$ David Armitage, 'The Scottish Vision of Empire: Intellectual Origins of the Darien Venture', in John Robertson, ed., A Union for Empire: Political Thought and the British Union of 1707 (Cambridge: Cambridge University Press, 1995), pp. 97-118; Armitage, 'Making the Empire British: Scotland in the Atlantic World 1542-1707', Past and Present, no. 155 (May 1997): 34-63; Armitage, 'The Scottish Diaspora', in Jenny Wormald, ed., Scotland: A History (Oxford: Oxford University Press, 2005), pp. 272303.

${ }^{17}$ Bolingbroke: Political Writings ed. David Armitage (Cambridge: Cambridge University Press, 1997); see also David Armitage, Armand Himy and Quentin Skinner, eds., Milton and Republicanism (Cambridge: Cambridge University Press, 1995).

${ }^{18}$ David Armitage, The Ideological Origins of the British Empire (Cambridge: Cambridge University Press, 2000). 
doing research on him, I discovered that there was no modern edition of his writings, and there deserved to be. So a left-hand project in the context of my other work was to bring Bolingbroke back to some prominence in the context of the blue book series, edited by Skinner, who had written the most important classic essay on Bolingbroke many years before. Skinner was very receptive to the idea of publishing Bolingbroke's writings in the Cambridge Texts in the History of Political Thought series.

Theories of Empire, published in 1998, was a collection of previously published essays. ${ }^{19}$ The hardest part of putting together that volume was to find anything on the Dutch empire. I wrote to various Dutch historians, including Prof. Piet Emmer at the University of Leiden, to ask whether there was one classic essay on Dutch ideas about empire. Emmer replied: 'sorry, the Dutch had no ideas; they just counted. There is no secondary literature on the intellectual history of the Dutch empire'. Consequently, I included in the volume the classic essay 'Freitas versus Grotius' by C. H. Alexandrowicz (1902-75). This led to an abiding interest in Alexandrowicz's work as perhaps the first post-colonial historian of international law, who anticipated by two decades the 'Third World Approaches to International Law' school, which has more recently transformed the field of international legal studies. Together with Jennifer Pitts of the University of Chicago, I will shortly publish a collection of Alexandrowicz's scattered but germinal essays. ${ }^{20}$

My doctoral dissertation was mostly a collection of case studies, which were published separately as articles or led to other projects, such as the edition of Bolingbroke's political writings. The Ideological Origins of the British Empire, published by Cambridge University Press in 2000, contains just a chapter and a half or maybe two chapters of my doctoral dissertation. The rest was freshly researched. Much to the anxiety of my colleagues at Columbia University, the monograph appeared just weeks before the tenure-file went forward. It was a risky strategy for any junior scholar in the American tenure system. Do not try this at home! I was very, very lucky to have the extra time (i.e. a junior research fellowship at Emmanuel College and research support from Columbia University) to write the book the subject deserved.

Should we characterize the period 1993-2004 as the 'Atlanticist' decade of your career?

Yes and no: yes, in the sense that most of the work which I published during that period was either explicitly or implicitly Atlantic in focus, and no, in the sense that the transition to international/global history was already taking place in 1999/2000. There was an obvious overlap between my Atlanticist and international/global interests. The focus on global history was firmly in place when I became Fellow at Harvard's Charles Warren Center for American Studies in 2000/2001, ${ }^{21}$ starting my project on the 'Foundations of

${ }^{19}$ David Armitage, ed., Theories of Empire, 1450-1800 (Aldershot: Ashgate, 1998).

${ }^{20}$ C. H. Alexandrowicz, The Law of Nations in Global History, ed. David Armitage and Jennifer Pitts (Farnham: Ashgate, forthcoming).

${ }^{21}$ The Warren Center theme in 2000/2001 was "Global America: Connections between Developments in America and in Other Parts of the Globe": http://news.harvard.edu/gazette/2000/05.18/warren.html. 
Modern International Thought'. Out of that project grew-some might say metastasized - a single chapter, which turned into a book, entitled The Declaration of Independence: A Global History (2007). ${ }^{22}$ My year at the Charles Warren Center was filled with a series of very intense, very fertile conversations with international and global historians, led by the late Ernest May (1928-2009), Akira Iriye, and James Kloppenberg. I really began to discover that I was an international historian or had been one all along, like some sort of scholarly Monsieur Jourdain. ${ }^{23}$ I was thus becoming an international and increasingly global historian on top of being an Atlantic historian. That is when the conversion really began to take hold, during that year.

The British Atlantic World, 1500-1800 (2002) was workshopped at a meeting of the International Seminar on the History of the Atlantic World at Harvard University in September 2001. On that occasion, you presented your now classic essay "Three Concepts of Atlantic History", which has been rather extravagantly compared to Marx's Eighteenth Brumaire of Louis Bonaparte for its quotable opening line, "We are all Atlanticists now". ${ }^{24}$ But what was the connection with international/global history? This interviewer attended the workshop, but never felt the connection with her own work. As Bernard Bailyn once put it, 'Martine insists on doing the East Indies'. ${ }^{25}$

The boundaries have broken down more since. We can now recognize each other as being part of the same enterprise: l'histoire des deux Indes, if you will. That was not always the case. ${ }^{26}$

National boundaries seem to have been reintroduced in Atlantic History, which defies the purpose.

Absolutely, partly because of volumes like The British Atlantic World, 1500-1800, insisting that there is something British about it. We had thought, perhaps naively, that it might generate a series of volumes on the French Atlantic World, the Portuguese Atlantic

${ }^{22}$ David Armitage, The Declaration of Independence: A Global History (Cambridge, Mass.: Harvard University Press, 2007).

${ }^{23}$ In Molière's play, Le Bourgeois Gentilhomme (1670), the eponymous bourgeois M. Jourdain aspires to be an aristocrat, only to make a complete fool of himself; in the process, he discovers that he has been speaking "prose" all his life without knowing it.

${ }^{24}$ David Armitage and Michael J. Braddick, eds., The British Atlantic World, 1500-1800 (Basingstoke: Palgrave Macmillan, 2002; expanded edition, 2009); http://www.atlantichistory.com/Atlantic_History/Atlantic_History_Home.html.

${ }^{25}$ Martine van Ittersum, Profit and Principle: Hugo Grotius, Natural Rights Theories and the Rise of Dutch Power in the East Indies, 1595-1615, Brill Intellectual History Series (Leiden: Brill Academic Publishers, 2006); though see van Ittersum, "Mare Liberum in the West Indies? Hugo Grotius and the Case of the Swimming Lion, a Dutch Pirate in the Caribbean at the Turn of the Seventeenth Century", Itinerario 31 (2007) pp. 59-94.

${ }^{26}$ See, for example, H. V. Bowen, Elizabeth Mancke and John G. Reid, eds., Britain's Oceanic Empire: Atlantic and Indian Ocean Worlds, c. 1550-1850 (Cambridge:

Cambridge University Press, 2012). 
World, the Dutch Atlantic World, etc. Happily, none of those happened, otherwise it could have been even more entrenched than it is. In some ways the cynics may be partly correct in saying that Atlantic History was a way of rescuing different national historiographies by putting them in broader contexts. Early American history became Atlantic History, parts of early modern British History became Atlantic History, and the same happened with the early modern histories of other European countries that had overseas connections or empires.

To do proper Atlantic history requires the knowledge of so many languages that is very difficult for anyone to do that.

Yes, perhaps it can only be done as a collaborative enterprise.

Were you influenced by Prof. Bernard Bailyn's conceptualization of Atlantic history? Bailyn first outlined his ideas for the International Seminar on the History of the Atlantic World in the Itinerario interview of March $1996 .^{27}$

Absolutely, yes. I presented a paper at the International Seminar on the History of the Atlantic World at Harvard University in August 1997, i.e. the second year that the August seminar was running. I continued to attend the annual seminars until 2005. Although I was already making the turn towards international history, I consider the Atlantic seminars among the most fertile forcing-houses for historiographical innovation that I have ever been part of. Bailyn's vision, ever expanding, ever deepening, was extraordinary to see unfold in the early years of the seminar. I was very privileged to have had a ringside seat for that.

What is your position with regard to FEEGI discussions about hemispheric history versus world history and European expansion versus world history?

My answer is twofold: 1) This is perhaps a trivial point, but I have not been directly engaged in discussions, face-to-face, with groups like FEEGI, to thrash them out. 2) To make a more substantial point, I am a great believer in letting at least a thousand flowers bloom. One should not be exclusive about these things. It all depends on the question you want to answer. Turning that around, the framework that you choose to bring to bear on your materials will generate new kinds of questions as well. There is a reciprocity, a back and forth, between the problems and the methodologies available to solve them. Prescriptivism is death in these matters. One should not legislate for one approach or another. All approaches should be in play in order to generate the questions to open up the archives and to create the discussions that are necessary to solve particular problems. That is the only reasonable answer to that question.

It is also sitting on the fence a bit.

${ }^{27}$ Bernard Bailyn, 'The Idea of Atlantic History', Itinerario 20 (March 1996), pp 19-44. 
Yes, I always remember what David Lloyd George said of an opponent in the British House of Commons: 'he has been sitting on the fence so long that the iron has entered his soul'. I feel very much that way myself: uncomfortable yet implacable.

You say that international and global history has been at the forefront of your mind since your year at the Charles Warren Center. At Harvard, you find yourself in good company: Niall Ferguson, Charles Maier and Emma Rothschild, to name a few, are extremely distinguished historians of empire. ${ }^{28}$ Has the Harvard History Department gone global? Are we all global historians now?

Those are two separate questions, but connected. Yes, what I have found most hospitable about the Harvard History Department is precisely its long-running commitment to international and global approaches. The two great innovators of International History were Ernest May and Akira Iriye, with more than seventy years of teaching at Harvard between them. They had laid the groundwork for this approach with their own students for the broader tenor of the Department long before any of the recent generation of imperial historians was appointed.

\section{But both May and Iriye did/do modern history.}

Yes, both published on modern history, but both were also deeply learned in earlier periods. Most of their Ph.D. students did topics in $19^{\text {th }}$ and $20^{\text {th }}$ century history, and therefore the field could be identified with that era to some extent. But there was never any hostility to earlier periods. Part of the raising of awareness about international and global history has been a breaching of chronological boundaries. For example, if we conceive of international history in terms of the interaction of both national and nonnational histories, then before the great age of nation-states, before the cementing of a regime of nation states, all history was ipso facto transnational or international history. I would insist upon that. My colleagues in medieval history do as well. Pre-modern history (i.e. history before the late $18^{\text {th }}$ century) is ipso facto, by definition, by its construction, a trans-national historiography, although it has only very recently been conceived of in those terms. Possibilities for dialogue with more self-conscious international/transnational/global historians are opening up, across chronological as well as geographical barriers. That is something the History Department at Harvard is very hospitable to - as are larger swathes of the historical profession, at least in the US. And a good thing too! That is something I am quite evangelical about. I am not on the fence about that at all.

To answer the larger question, are we all global historians now? No, not in the sense that we are all doing global history. We certainly are in the sense that all historians now have

\footnotetext{
${ }^{28}$ Niall Ferguson, Empire: How Britain Made the Modern World (London: Allen Lane, 2003); Charles S. Maier, Among Empires: American Ascendancy and its Predecessors (Cambridge, Mass.: Harvard University Press, 2006); Emma Rothschild, The Inner Life of Empires: An Eighteenth-Century History (Princeton, NJ: Princeton University Press, 2011).
} 
a global audience, thanks to the Internet. But in one strong sense we could say that we all have to be global historians now. By that I mean, if you are not doing.... this formulation will get me into trouble, but let me nevertheless put it in these strong terms: if you are not doing an explicitly transnational, international or global project, you now have to explain why you are not. There is now sufficient evidence from a sufficiently wide range of historiographies that these trans-national connections have been determinative, influential and shaping throughout recorded human history, for about as long as we know about it. The hegemony of national historiography is over. It used to be the case until very recently, let's say ten years ago, that if you did not do national historiography, you had to tell other people why you were not doing national historiography. I would like to say the boot is now on the other foot. We now have to ask the national historians: why are you doing US history without the history of the hemisphere, the American empire, America's relations with the wider world, the history of American emigration, the transnational circulation of ideas, whatever it may be? I think it is time for us to put the national historians on the defensive, to justify their choice of particular local, regional or national frameworks. I am putting that a little aggressively, but I also hope that it might be productive for those who work on smaller units, to justify to themselves why it is they choose them - apart from the inertia of the historical profession, that it has always been the case that one would take a town, a region, or a nation-state as a focus of historical study. We need to be more reflexive about exactly why we choose those things, rather than the path-dependency of historiographical activity.

The irony is that many historians born and/or living in newly independent countries in the so-called Third World are doing national history.

Yes, it is essential for them do so; it is essential for the public purposes of their historiography, because of the former suppression. It is absolutely essential for them to go through that stage. Is it essential for US or British historians to continue doing national history for the same reasons? There is no equivalence there. If historians find themselves in a post-imperial, not a post-colonial, situation and if they continue to write national history, then we have to ask why. They need to justify why they are doing what they are doing, when there is so much evidence that the nation-state is a container at once too small and too large to encompass everything that we want to learn about the past.

Does it not also depend on the audience historians are writing for? Historians have a duty towards society, their own societies, hence the predominance of the nation-state in historical narratives. It feeds into national identity, any identity. That is what people are interested in. As an ideal, we should do global history. But we are all rooted in our local communities.

I agree. History has a public, indeed a civic function in that sense. But to take the example of the US, we now know from the latest census analyses that white descendants of Europeans are already in the minority. ${ }^{29}$ That necessarily changes the public and civic

${ }^{29}$ http://2010.census.gov/2010census/data/. 
focus of US historians. They should not continue to tell the story of the nation-state as the advance of European immigrants and the embedding of their institutions, but tell the full story, the diversity of the US in its connections with the wider world --oceanic, hemispheric, and global. So, yes, there will be conservatives who say 'the national story should continue to be the story that has been told by the New England historians since the beginning of the $19^{\text {th }}$ century'. However, that story will increasingly lose an audience because that audience is dying off, and being replaced by a much more diverse audience, with a much greater consciousness of transnational connections, not least through their own family lives.

The general public is mainly interested in genealogy and local history. That is what you see all around you, especially in the Boston area-lots of historic sites associated with the American Revolution. In order to keep in contact with the larger public, universitytrained historians should have a feel for that, while showing at the same time the larger implications.

One of the impetuses behind my book on the US Declaration of Independence was precisely to show that this most American of American documents was fundamentally international, even global: if one could globalize the Declaration, then there was no reason not to globalize the rest of American history-by which I mean, as most of its practitioners mean, United-States-ian history. Even in its physical make-up the Declaration was an international object, printed by an Irishman, using a printing press and type imported from England. Moreover, he printed it on Dutch paper. There were no paper manufacturers in British North America in the 1770s. The US would not become self-sufficient in paper production until the early $19^{\text {th }}$ century. Even the paper the Declaration was written on had to be imported. The inkstand used to sign the manuscript was made of silver not from the mines of Virginia, but probably from the mines of Peru. So it does not take very much to show the international connections, even in the Declaration's physical fabric.

The Declaration of Independence: A Global History (2007) is now available in paperback. More importantly, it has been translated into Italian, French, Portuguese, Spanish, and Japanese. A Chinese translation is underway. Does this make you a public historian? Was it your intention to speak to a wider audience? That book grew out of your forthcoming Foundations of Modern International Thought. Did you ask Harvard University Press to publish one chapter as a separate book?

Oddly enough, it was actually my editor at Harvard University Press, Kathleen McDermott, who suggested the idea to me of doing a separate book, as something that could reach a wider audience. I was very happy to do that. I was quite bullish about taking a broader, international and global approach to early American history in general. Harvard University Press very generously, very wisely saw the potential for a book on that subject, a relatively short book that would bring that perspective to a wider audience. One of my great satisfactions is the way in which the book has been read by nonacademic readers, including high school students. I have done a lot of talks to high school teachers, in particular about how to teach the American Revolution in wider contexts. 
That seems to be an important shift in the teaching of American history in American high schools. ${ }^{30}$ Teachers have realized the necessity of taking a broader, cosmopolitan perspective to educate their students about the wider world that they are part of. For civic purposes, the national narrative is no longer sufficient for them. I am very proud indeed to have made a small contribution to that. I have the satisfaction of seeing my research go very quickly into classrooms across the US.

Were there any negative reactions to your interpretation of the Declaration of Independence?

Yes, it was written as a polemical work. I deliberately downplayed the importance of the Declaration's second paragraph (i.e. 'self-evident truths' and 'inalienable rights') because historically it has been much less important to the global context than the opening and closing paragraphs regarding the rights of peoples and 'Free and Independent States'. But I did get some pushback from American historians and Americanists, who claimed the book was unbalanced in not giving due attention to the importance of the second paragraph for American history itself. ${ }^{31}$ But that work - placing the second paragraph into its larger, historical context - has been done as well as it is likely to be done by Pauline Maier in American Scripture (1998). ${ }^{32}$ Her book was a great inspiration to me. So I said to myself: 'my job now is to place the whole document into its international context in 1776 and beyond, and see what the evidence turns up'. And the evidence was very decisively against the importance of the second paragraph. That did get me into some kind of trouble. The way that I tend to teach that, especially when I work with high school teachers, is to say: "it is important to remind your students that the promises of the second paragraph, the promises of individual rights, the broader promises of human rights, are always contestable and reversible, not something you can absolutely rely upon'. One of our jobs as teachers is to encourage our students to make arguments in favor of those rights, not to assume that these rights will always be available to them or to anybody else. Come up with good arguments why this conception of rights, natural rights, rights perhaps derived from a divine source, rights derived from major foundational documents like the Declaration of Independence or the Bill of Rights are substantive and can be actionable, can protect you. How do you gain protection from that? Only by protecting the rights themselves, by being able to argue for them. My skeptical view of the second paragraph is very much intended to push in that kind of civic direction: to say, well, justify these arguments. There are plenty of philosophers who say that the assumptions underpinning the second paragraph of the Declaration of

${ }^{30}$ Gary Reichard and Ted Dickson, eds., America on the World Stage: A Global Approach to US History (Chicago: University of Illinois Press, 2008).

${ }^{31}$ Laurent Dubois, Robert Ferguson, Daniel Hulsebosch and Lynn Hunt, "Critical Forum," William and Mary Quarterly, $3^{\text {rd }}$ ser., 65, 2 (April 2008), pp. 347-69; Tiziano Bonazzi, David Hendrickson, Peter Onuf and Arnaldo Testi, "Round-Table on Armitage, The Declaration of Independence: A Global History," RSA: Rivista di Studi Nordamericani, 20 (2009), pp. 79-108.

${ }^{32}$ Pauline Maier, American Scripture: Making the Declaration of Independence (New York: Vintage, 1998). 
Independence are, to put it mildly, not very robust. We may need to come up with better arguments in their favor. So what might those better arguments be, instead of the shorthand assumptions that Jefferson built into the document?

Do Harvard historians have a duty to speak to the general public? Many of your colleagues are writing in the big American newspapers, weekly magazines etc. Is it valued by the Harvard administration?

Maybe not a responsibility, but certainly an opportunity. The Harvard name does open doors. The inspiration provided by colleagues who have a public presence encourages one to rethink how to couch one's scholarship to reach a wider audience. On the part of the administration, there is an expectation that one should speak to the widest possible audience. The EdX initiative may become important in this regard as well. Instead of having at most one thousand students in a physical classroom at Harvard, it will now be possible to have tens of thousands of listeners and learners all around then world.

What will be History's contribution to the joint MIT-Harvard EdX initiative (http://www.edxonline.org/)?

I was at a meeting a few days ago to discuss Harvard's entry into the world of "massive open online courses" (MOOCs). The very first on-line Humanities course to be offered through EdX will be a course on Chinese history taught by my colleagues Peter Bol and Bill Kirby. They are working on it right now. There is a potential audience of over a billion in China alone.

But there would seem to be a problem if the History contribution to EdX would be nothing more than a Harvard History professor pontificating in front of a camera, expecting the world to watch in breathless admiration.

That is true. That turns out to be very unappealing to an on-line audience. That is where the really interesting questions begin. We had a two-and-half hour discussion about this. How do you do what we do as interpretative, evaluative, qualitative scholars in that kind of scaled-up, massive on-line environment? It is fine for introductory courses in mathematics or computer science: almost all on-line courses so far have been of that kind. They are introductory; they can easily be accessed by non-human assessors, through multiple-choice questions and machine-marking, for example. It really is a matter of advancing stage by stage from simple to more complex information. It does not involve evaluation or analysis of the materials. So the really interesting questions are: 'how do we do what we do in that kind of environment? Is it even possible for us to do what we do in that kind of environment?'. That is one reason why Harvard and MIT are investing a large amount of money in the EdX initiative. It is a very good program in the sense that Harvard, in particular, has said: 'this will not just be for the sciences and engineering, this will also be for the Humanities and Social Sciences'. Harvard has now turned it over to all of us, asking 'well, how will it be?' 'What kind of resources can Harvard put your disposal to create on-line the kind of analytical experiences that we value in our classrooms?'. There are various possibilities, of course. It could mean 
digitizing texts and physical objects, in order for students to zoom in and view and rotate them in three-dimensional space. It could mean allowing various kinds of on-line discussion, perhaps with off-site, but on-line teaching assistants. Or it could be done through various kinds of peer advising and peer teaching, i.e. more-experienced students help less-experienced students in on-line discussion groups. Students who take an online course for some kind of credit become teachers for that course in due course. It is creating a wholly different kind of teaching environment, and at an international and global scale. A professor who teaches a course on leadership at the Kennedy School of Government at Harvard told us at the meeting on Wednesday that he had to rethink the course in light of the cross-cultural, international conceptions of what leadership means, which he got back from the ten thousand students who were taking the course on-line. They were feeding back very different conceptions of leadership. He brought along a student from Serbia who was a graduate of the on-line course, who had come to Harvard to take a Masters degree at the Kennedy School and is now teaching on the course here. Contact with actual, living subjects changed the way this professor taught the course at Harvard. Another participant said 'we now have a huge survey group for testing pedagogical innovation'. You can try a new technique or module, and get immediate feedback from ten thousand students, whether it works or does not. That can take years in a normal classroom. A third participant mentioned the possibilities for crowdsourcing in research, such as the Transcribe Bentham project in London, which uses nonacademics to crowdsource scholarship itself. ${ }^{33}$ That could come through courses as well, i.e. to have certain core texts or materials that people can use for research. It is possible to begin to imagine ways in which we can build in research and analytical experiences in on-line courses that are unimaginable in a classroom of between 20 and 120 students, but become conceivable when you are scaling up to ten thousand students. It could create very different, novel, previously unimaginable ways of teaching and doing collective research, which are not possible in a small, classroom setting.

\section{Is EdX going to be one of your priorities as Chair of the History Department at Harvard?}

It cannot be formally a priority, because for the moment $\mathrm{EdX}$ is something the faculty do in their spare time. It is a non-profit organization, independent from both universities. The members of the board are senior administrators, including the presidents, provost and deans of both Harvard and MIT, etc. Right now, Harvard faculty members are asked to contribute pro bono and pro fama - they can become famous and reach a larger audience. However, there is no salary recognition for it. It is like writing a textbook, which you also do in your own time. Crucially, there is no business model for it yet. Nobody has figured out how to generate a revenue stream out of this kind of higher education. Until somebody works out how to do that, EdX may continue to be something that you do out of a passion to reach a larger audience and that the universities like Harvard, MIT and Stanford will undertake to expand their brand. Part of the down-side of these on-line

${ }^{33}$ On this innovative project in editorial crowdsourcing, see Tim Causer, Justin Tonra and Valerie Wallace, "Transcription Maximized; Expense Minimized? Crowdsourcing and Editing The Collected Works of Jeremy Bentham", Literary and Linguistic Computing 27, 2 (March 2012), pp. 119-37. 
courses is the drop-out rate: at best $90 \%$, at worst $97 \%$, of the people who signed up do not see out the course until the very end. This is no reason not to press ahead: even if such a huge proportion of students do not make it the end of the course — or, in most cases, even get past the beginning - thousands still may. As the best recent analysis of MIT's first on-line course concludes, 'the message for MOOCs has to be: disregard the dropouts and celebrate giving huge numbers of people access to free, high-quality, education'. ${ }^{34}$ To retain students, smaller modules are being developed for EdX, i.e. 4-5 week modules, rather than the 13-14 weeks of the Harvard teaching semester. So that is the question, how do you keep people's attention, when they do not have regular class assignments, when they are not doing it for credit? In some cases, you can get a certificate of completion, but that does not have any credibility for employers, as an academic qualification, unless you can find a way to make it more robust, and, essentially, to sell those kinds of accreditation. It is not clear how you monetize this kind of higher education. There are all kinds of question, very interesting, fundamental questions. What are the university's responsibilities towards a wider audience beyond its gates? How can faculty members reach out, under what circumstances, with what kind of encouragements? It is all fascinatingly up in the air. But this is just a tiny corner of the much bigger digital revolution that is taking place now. I am absolutely certain that we are in the midst of the single most transformative moment in academic life since the modern research university was created at the end of the $19^{\text {th }}$ and the beginning of the $20^{\text {th }}$ century. In five years time, the landscape is going to be unrecognizable. It is already becoming unrecognizable in fundamental ways.

You mean new formats of publishing, secondary literature with direct links to primary sources and other secondary literature, possibilities to annotate e-books on-line, etc?

Of course: six different layers of annotation, books themselves becoming wikified, through their interactions with past scholarship and later readers. This is already happening, it is already here. That is where I feel very strongly that we have an agenda to follow. That is an agenda that I am already putting into place for the History Department at Harvard. I have set up a Digital Working Group for the Department. We have more than ten faculty members who are actively engaged in rethinking pedagogy and research, using digital tools and materials. I take that to be our major issue now: to publicize which is already going on in the Department-there is huge amount of innovation in this area which is not as well known as it should be - and to equip all of our students and as many faculty as want to be equipped with these digital capacities, because they are rapidly becoming essential for everything that we do. Some familiarity with how they operate is going to be as basic as philology was to a classical historian, for instance. We need to realize that this has already happened, but we are lucky to have some of the field's great innovators here at Harvard to give advice and inspiration. ${ }^{35}$ What we are

\footnotetext{
${ }^{34}$ Sue Gee, "MITx: The Fall-out Rate" (16 June 2012): http://www.iprogrammer.info/news/150-training-a-education/4372-mitx-the-fallout-rate.html. 35 Jonathan Shaw, "The Humanities, Digitized: Reconceiving the Study of Culture," Harvard Magazine, May-Jun 2012: http://harvardmagazine.com/2012/05/the-humanitiesdigitized, featuring the work of, among others, Peter Bol, Jo Guldi, and Jeffrey Schnapp.
} 
doing now is playing catch-up. As one of participants of the Wednesday meeting [about $\mathrm{EdX}]$ put it, 'Putting together these large on-line courses now is rather like driving a very rapidly moving train, when you have to construct both the engine and carriages behind you and lay the track in front of you, at the same time as the train is moving at a hundred miles an hour'. That is the way it is going in all areas now. I am absolutely convinced of that.

But that is a Western phenomenon, is it not? In his essay 'Codex in Crisis', Anthony Grafton recalls that he was sitting in a "tin-roofed, incandescently hot West African internet cafe" in 2005, trying to answer e-mail questions from his graduate students in the US. He could find "little high-end material on the screen, and neither by the look of things, could [his] Beninese fellow users. "36

There are digital divides within the US as well. As with any valuable resource, very rapidly inequalities kick in. We have to be aware of that. There is a lot of discussion within, for instance, the digital community in the US about these inequalities of access and how digital access can overcome them to create more connected forms of public history and community history, to have history literally from the bottom up. For example, local groups crowdsourcing materials from their own communities, feeding them into on-line archives, where these can be supplemented by historians, but in a nonhierarchical relationship between professional historians and non-professional people interested in history and with access to historical materials. That is great, but you are absolutely right, the conversation has to be expanded outside the wealthy heartlands of the digital world. In terms of academic institutions, we have immense computing power -large amounts of money are being put behind it here. But that is not true everywhere, even within the relatively well-funded higher education system in the US. Most students and scholars do not have access to the full range of databases that exist behind high and costly pay-walls. So, yes, what about Benin, what about India, what about many other parts of the world, even Latin America, for instance, how will they get access to these tools and techniques? That is a question that goes beyond the capacity of academics, but that is a one that we have to consider in so far as the promise of the digital revolution is universal access to things that had so far been allowed only to the privileged and accredited few. Open-access journals, creative-commons licenses and the various efforts to digitize vast numbers of books through the Internet Archive, Google Books, the Digital Public Library of America, the Europeana project, as well as national projects in countries such as France and Germany, will in time all help to create that universal access to the world's knowledge.

Do you consider your work to have moral implications? The reasons why I am asking this is your contribution to a recent symposium in the journal Political Theory (2011) on the work of the Canadian political theorist, James Tully. In your contribution, you appear to criticize Tully, a major defender of the rights of indigenous peoples, for ignoring 'the tens of millions of people [in the global South] who still lack some of the

${ }^{36}$ Anthony Grafton, Worlds Made By Words: Scholarship and Community in the Modern West (Cambridge, Mass.: Harvard University Press, 2009), p. 302. 
most basic forms of human security'. Should historians leave it to philosophers to consider these moral issues? ${ }^{37}$

It was certainly meant as a friendly provocation to Tully, very much in his own critical spirit, to say we should not settle with the boundaries of moral and political philosophy as we have inherited them, we should always be seeking to expand them, if we believe that there is any transformative potential whatsoever in our use of historical knowledge to enlighten contemporary society and open up new questions. I was pushing the boundaries of what he had done. His work has been absolutely fundamental, not just in Canada or North America, but more broadly in bringing indigenous rights to the center of discussion in political theory. That is a huge achievement in itself. I was just pushing the logic of that further, by saying 'so what about those people who cannot make claims within the context of settled and constitutionalized societies like Canada, the US or Australia, those for whom the struggle might not be about recognition, but for simple, bare human survival?'. How can this be made relevant to them? How can we think about other kinds of inequalities on a global scale which are parallel to and to some extent intersect with the kinds of inequalities which Tully himself was mapping in the context of a very large and very important set of communities, but only one congeries of communities on that global scale?

Should historians consider these questions as well?

How can we not? It depends on your choice of topic, of course. But the topic I am working on at the moment, competing conceptions of civil war, ${ }^{38}$ is something that affects hundreds of thousands of people around the world, not just in Asia and Africa, but now in the Middle East as well. To ask about the boundaries of humanitarian law and civil law, to ask how external powers should react to conflicts called civil war, this can literally be a case of life and death for tens of thousand of people, perhaps even millions of people. If one encounters a topic like that, I think there is a moral responsibility to consider the wider ramifications of one's academic work. Anything that one writes may be taken up in these contexts. One therefore has a duty to get it right, to consider the potential implications, what uses it might be deployed for.

Finally, how might you define the future of Intellectual History?

${ }^{37}$ David Armitage, Rainer Forst, Bonnie Honig, Duncan Ivison, Anthony Simon Laden, and James Tully, 'Feature Symposium: Reading James Tully, Public Philosophy in a New Key (Vols. I \& II)', Political Theory 39, no. 1 (2011), pp. 112-65, on James Tully, Public Philosophy in a New Key, 2 vols. (Cambridge: Cambridge University Press, 2008).

${ }^{38}$ David Armitage, Civil War: A History in Ideas (New York: Knopf, in progress). 
My answer is three-fold: 1) International/Global, 2) Longue Durée, and 3) Digital, which facilitates 1) and 2). I have been writing recently on all of three of these futures. ${ }^{39}$ In regard to all of them, my preference is for short books on big topics. They are more readable; they have more of an impact. One can move more rapidly. At some point, somebody has to digest the findings of the big books, to put them into a bigger picture. And to do that within the compass of, let's say, between 30,000 words and 150,000 words for a wider audience is absolutely essential, if we are going to have any kind of impact. And also to do that in other fora. We are still talking in terms of the physical dimensions of the codex. Again, the Digital Revolution means that we are now writing in different genres and reading in different genres. Now, much of the most exciting stuff that I read is in blog-posts, it is not in journals, to some extent it is not in monographs. Very rapidly moving, suggestive, deeply researched scholarship is coming out in very different formats now. I joined Twitter recently: the amount of information, fabulous information, one can get from that is absolutely mind-boggling. I have learned an incredible amount from the links that people have put up-there's very serious material to be found there if you follow the right people.

The problem is that in Britain they have not caught up with this.

Of course, they have. Many the people I follow are in Britain. They put up links to the Folger Shakespeare Library, to the Institute of Historical Research, to digital projects at the University of London, etc., etc.- an incredible amount of stuff. And much of the most important digital work is being undertaken by scholars in Britain: King's College, London, has a Department of Digital Humanities, Oxford has an increasingly prominent and integrated programme in the field, and the world's largest digital archive of subaltern sources, the Old Bailey Online, comes out of three British universities.

But none of this counts for the Research Excellence Framework (the United Kingdom's regular process of academic assessment)! $!^{40}$

This is the problem, a really interesting and critical problem. How do we evaluate digital scholarship in non-traditional formats? The American Historical Association-following the Modern Languages Association - has just set up a committee to create protocols for evaluating digital scholarship. ${ }^{41}$ That is at least a start. That is one of things that I have asked our Digital Working Group in the Department to do, to create standards for the evaluation of digital work for junior faculty, graduate students and undergraduates - we are likely to get increasing numbers of undergraduate theses that involve digital work.

${ }^{39}$ Armitage, Foundations of Modern International Thought; Armitage "What's the Big Idea? Intellectual history and the Longue Durée," History of European Ideas 38, 2 (2012); Armitage and Jo Guldi, "The Return of the Longue Durée" (in progress). 40 http://www.ref.ac.uk/.

41 http://www.mla.org/guidelines evaluation digital. The AHA "approved the establishment of a Task Force on Digital Scholarship" at its June 2012 meeting: http://blog.historians.org/news/1664/decisions-of-the-aha-council-june-2012. 
And we have no standards for evaluating that at the moment. In a year's time, we have got to have them. That is a real imperative.

According to Neil Jefferies, the Bodleian Library in Oxford will soon make its entire catalogue open-source, thus allowing scholars to make changes in the catalogue. ${ }^{42}$ But there is only an incentive for people to do this if they are going to receive some sort of recognition for it.

Not necessarily. Go to any rare books library in the US or Britain and you will often find a slip of paper in the front of a book - or people have made annotations - about where extracts have been published, about other manuscripts, attributions, and so on. We have always have had an informal version of that sharing of scholarly knowledge in and alongside the physical objects. But the planned changes in the on-line catalogue of the Bodleian Library will massively increase that possibility. Harvard Libraries have made available the meta-data on 12 million-12 million! - objects in the Harvard collections manuscripts, books, physical materials, etc. ${ }^{43}$ If you can wait a couple of hours, you can download the whole ZIP file of, basically, two-thirds of the library collection. And then the kinds of searches you can run on that, the way that you can manipulate that material... the sky's the limit. It is up to you. That is all open-source now, that is all there. That is like being able to see inside the whole card catalogue all at once, but on a ten-fold scale.

Is there anything you would like to add to conclude our interview?

I am sorry that I do not have the standard stories of how I spent six months on a banana boat, chatting to the Indonesian crew. I have read a few of these Itinerario interviews: I am sorry I do not have more glamorous or romantic stories for you!

I would however like to mention the Cambridge University Press series, Ideas in Context which I co-edit and about which I feel very strongly. ${ }^{44}$ Speaking of the future of intellectual history, we are pushing the series very much in the direction of doing more on imperial ideologies and global intellectual history. We just published Chris Bayly's recent book on Indian liberalism: the $100^{\text {th }}$ volume in the series, symbolically to show a new direction for the series and for the field of intellectual history as a whole. ${ }^{45}$ Chris

\footnotetext{
${ }^{42}$ Neil Jefferies, Research and Development Project Manager at the Bodleian Library, Oxford, announced the planned changes in the on-line catalogue of the Bodleian Library at the 'Representing the Republic of Letters' meeting held at Huygens ING in The Hague, 30 June-1 July 2011.

${ }^{43}$ http://openmetadata.lib.harvard.edu/bibdata.

44 http://www.cambridge.org/gb/knowledge/series/series_display/item3937510/Ideas-inContext/?site locale $=$ en GB.

${ }^{45}$ C.A. Bayly, Recovering Liberties: Indian Thought in the Age of Liberalism and Empire (Cambridge: Cambridge University Press, 2012); compare Shruti Kapila, ed., An Intellectual History for India (Cambridge: Cambridge University Press, 2010); Kapila and Faisal Devji, eds., 'Forum: The Bhagavad Gita and Modern Thought,' Modern
} 
talked about the first glimmerings of this project in an Itinerario interview a few years ago. $^{46}$ I am happy to link up to that.

I am also convinced the next frontier for oceanic history is Pacific History. We are very glad to convene the conference at Harvard in November 2012. ${ }^{47}$ I think this will be the first conference ever to take a truly pan-Pacific perspective. It will include scholars who work on the indigenous Pacific, the histories of Australia and New Zealand, the history of Asia, including China and Japan, and also the North-Pacific, Russia as well as the Americas. The participants will see the Pacific whole for the first time, on the models of Atlantic History. We will need to figure out whether the models forged for Atlantic History have any relevance to an arena that is so much bigger, i.e. one-third of the earth's surface, one-sixth of humanity within its borders. The Pacific is a sea of islands - in the way that the Atlantic by and large is not — as well as a sea of rims and borders and connections. It is very exciting to see how that comes together. A volume should emerge from that by 2014 , designed after the British Atlantic World volume. ${ }^{48}$ The conference is the workshop for the volume.

It is important in terms of my global trajectory to say that I feel in some ways that I am repaying a debt to the Pacific world, and even carrying on my father's legacy. I hold an honorary professorship at the University of Sydney in Australia, where I like to visit as often as I can. There one sees the world from a very different perspective, a Pacific perspective. I have also been lucky enough to have two extended visits to Japan in recent years as well, where one gains another Pacific perspective. Putting together those perspectives and the conversations about Pacific history that I have had in both Japan and Australia over the years, it seemed to me that this was a topic whose future had very much come.

You asked earlier about the future of Atlantic History. I think one of the futures of Atlantic History is precisely joining it to other oceanic and trans-regional histories. That is part of the logic of what we discovered about the limits of Atlantic History: it can be too broad to encompass things but also too narrow to deal with trade flows, migration flows, and flows of goods and ideas. We need to think about the interrelations between these oceanic arenas and how in some sense they add up to a global or proto-global history. And there I end!

Intellectual History 7 (2010): 269-457.

${ }^{46}$ Interview with C. A. Bayly, "I am not going to call myself a global historian," Itinerario 31 (2007) pp. 1-14.

${ }^{47} \mathrm{http}: / /$ projects.iq.harvard.edu/pacific histories/.

48 David Armitage and Alison Bashford, eds., Pacific History (Basingstoke: Palgrave Macmillan, 2014), modelled on Armitage and Braddick, eds., The British Atlantic World, 1500-1800. 